\title{
Case Study: Emerging Advantages of Climate Change for Agriculture in Kano State, North-Western Nigeria
}

\author{
Moses Okemini Nwagbara \\ Department of Soil Science and Meteorology, Michael Okpara University of Agriculture, Umudike, Nigeria \\ Email: monwagbara@yahoo.com
}

Received 23 April 2015; accepted 20 June 2015; published 23 June 2015

Copyright (C) 2015 by author and Scientific Research Publishing Inc. This work is licensed under the Creative Commons Attribution International License (CC BY). http://creativecommons.org/licenses/by/4.0/ cC) (i) Open Access

\section{Abstract}

The current climate change is affecting the environment in diverse ways. Some of the effects are good and some others bad. The good side has not been given its deserved attention in Nigeria, nor has it in most parts of the world. Some areas are becoming warmer and wetter, which could enhance agriculture. This paper therefore examined the rainfall and temperature trends as tools of climate change over Kano State, north-western Nigeria, which is an area well known for agriculture. Rainfall and temperature data covering a period of 43 years (1971-2013) were collected and analyzed using the moving averages, regression and correlation statistics. Results obtained showed gradual but steady increases in both temperature and rainfall. The results indicate that Kano State is warming at an average annual rate of $0.011^{\circ} \mathrm{C}$ and becoming wetter at a rate of $21.26 \mathrm{~mm}$ per annum. An implication of this increased rainfall for farmers in the area is the opportunity to increase crop and animal production. This is because more rainfall can now be harvested. Also, soil moisture, rivers, dams, and ponds are being recharged more, thus making water more available and longer lasting for crops and animals.

\section{Keywords}

Climate Change, Trends, Crop Production, Animal Production

\section{Introduction}

Several studies of the earth-atmosphere system have confirmed the build-up of greenhouse gases in the atmosphere as being responsible for the present climate change via warming. See for example, [1]-[11]. Generally, the manifestations of this change are not the same globally since different regions are differently affected. Some of 
these manifestations have conspicuous effects on the environment. For example, droughts are becoming more frequent and prolonged the world over. Extensions of this are the expansion of desertification and its concomitant effects of withering of vegetation, famine, and drying-up and/or shrinking of water bodies and increased dust loading [12]-[16]. Also, there have been increased frequency and magnitude of coastal flooding emanating from powerful and destructive hurricanes propelled by strengthened storm systems [1] [17] [18]. The melting of glaciers and frozen sea water is now common [17] [19]. Similarly, the survival ability of some very sensitive living things like algae and corals has been altered [18]. Climate change also has its good effects though not often given attention to. For example, the increasing global temperatures are translating into increased agricultural productivity and better vegetation conditions for some regions as they become warmer and wetter. Habitable areas are enlarging for some once frozen regions as they get melted and warmer [19].

Though the tropics (or low latitudes), within which the study area is located is being the least warmed in the present warming of the world [19] [20], any warming at all still makes it an area of very high temperature which could cause an increase in rainfall levels or a reduction in them. Agriculture is one of such activities of man that might be affected by this because an increased rainfall implies more luxuriant growth and greater yields for crops and by extension more food for animals. On the other hand, a reduction in it, especially in combination with raised temperatures, brings about insufficient soil moisture which would result to withering of vegetation. This paper therefore assesses the good sides of climate change in the study area, especially with regard to agriculture.

\section{Area Description}

The study area is Kano State, north-western Nigeria. It is a typical tropical area as it is located between latitudes $10^{\circ} 30^{\prime} \mathrm{N}$ and $12^{\circ} 38^{\prime} \mathrm{N}$, and longitudes $7^{\circ} 45^{\prime} \mathrm{E}$ and $9^{\circ} 29^{\prime} \mathrm{E}$ (Figure 1). This location falls within the Koppen's Aw climate (i.e. Tropical Continental Climate) implying dry and wet type with the rainy season lasting from midMay to mid-October whereas the dry season is from mid-October to mid-May [21]. Annual rainfall totals for the northern part of the state are about $800 \mathrm{~mm}$ and $1100 \mathrm{~mm}$ for the southern part [22]. These rainfall amounts make the area to possess Sudan Savannah vegetation [23]. The mean annual temperature is about $26^{\circ} \mathrm{C}$ [24].

Kano state is not only the most populous state in northern Nigeria but in the country as a whole. The population of the state was 9,383,582 in the 2006 national population census [25]. Dividing this population with the state's area of 20,131 square kilometres, it means that the state had a population density of approximately 466 persons per square kilometre in 2006. It therefore has the highest population density among the states of northern Nigeria.

The study area is well known for its success in crop and animal production at both subsistence and commercial levels. These agricultural practices are mostly found in the outlying districts of the state with crop production

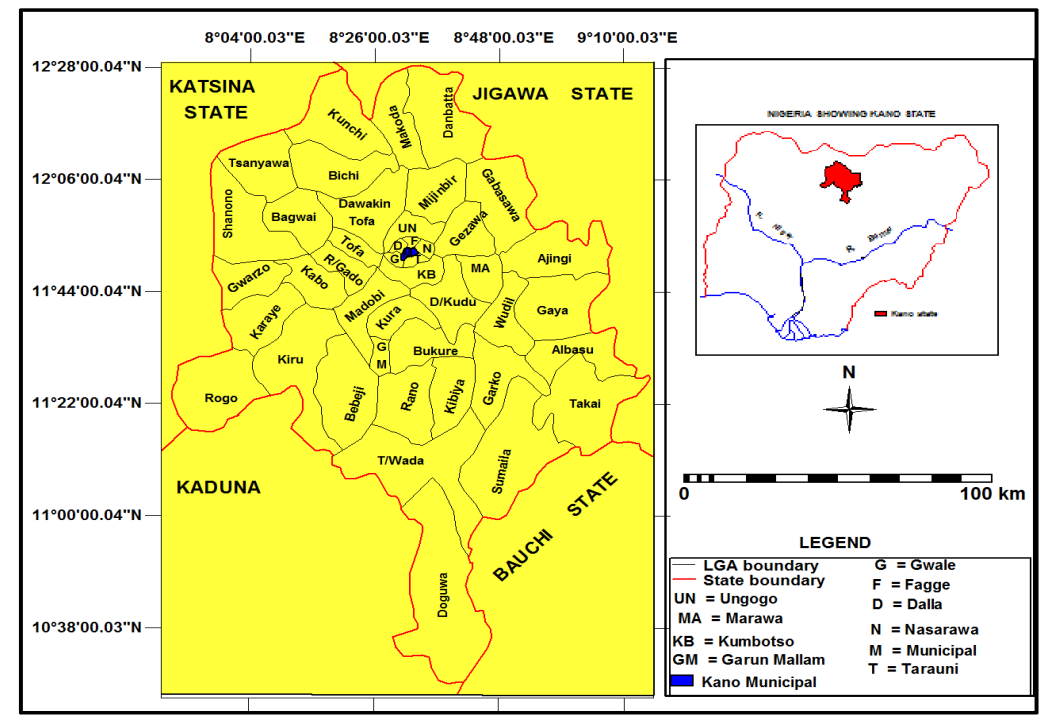

Figure 1. The study area: Kano State, north-western Nigeria. 
directly dependent on rain, and during the dry season on irrigation. Animal production also depends on rain, though indirectly to a reasonable extent. Maize, millet, sorghum and rice are major food crops produced for local consumption whereas groundnut and cotton are produced for export and industrial purposes. In Nigeria, Kano state is the major producer of hides and skins, chilli pepper, cotton, garlic, gum arabic, sesame and soybean.

\section{Materials and Methods}

\subsection{Data Used}

Mean monthly maximum and minimum temperatures and monthly rainfall totals covering 43 years each for the study area were collected from the Nigerian Meteorological Agency (NIMET), Oshodi, Lagos, Nigeria. Temperature and rainfall were used as indicators of climate change in the study area as these parameters are not only elements of weather and climate, but also factors of climate. The temperature data were transformed to mean monthly temperatures and furthermore to annual means. In transforming the mean monthly temperature values, 1032 months were available while those of 18 months were missing representing 1.7 percent. As for the rainfall data, monthly totals were transformed to annual totals. Nine (9) months were missing out of the 516 months involved representing 1.7 percent. This problem of missing values was resolved by the application of linear regression by which known values in the series were used to determine the unknown ones [26].

\subsection{Data Analysis}

The following statistical techniques were employed in the analysis of the climatic data: moving averages or running means; regression; and correlation. Their details are as follows:

Moving Averages: The 10-year moving averages technique is elected in this study to help filter out erratic variations (fluctuations) between successive observations in the temperature and rainfall data. Basically, the moving averages reduce the irregular fluctuations and highlight the regular ones [26]. The technique is good in revealing short term trends [27] [28].

Pearson's Product Moment Correlation Coefficient (r): It was used to examine the degree of association between time and temperature values and between time and rainfall values.

Furthermore, the Coefficient of Determination (CD) was applied to determine what percentage of variation in temperature or rainfall values is explained by time. It can be expressed as:

$$
\mathrm{CD}=\mathrm{r}^{2} \times 100 \%
$$

where, $r$ is the Pearson's Product Moment Correlation Coefficient.

To test for significance of the correlation coefficient, the Student " $\mathrm{t}$ " Test was utilized. It is written as:

$$
\text { Student " } \mathrm{t} \text { ” Test }=\frac{\mathrm{r} \sqrt{\mathrm{n}-2}}{\sqrt{1-\mathrm{r}^{2}}}
$$

where, $\mathrm{r}$ is the Pearson's Product Moment Correlation Coefficient and $\mathrm{n}$ is the number of observations (i.e. 43).

\section{Results and Discussion}

After filtering out erratic variations between successive observations by the use of the 10-year moving averages statistic, annual temperature and rainfall trend lines for temperature and rainfall respectively were fitted with few peaks and depressions left (see Figure 2 and Figure 3). Employing the linear regression statistic to suppress all modes of fluctuations, including those left by the moving averages technique, and to highlight the general tendency, intercepts, slopes and regression line equations were generated. The results so generated appear in Table 1 and as graphs in Figure 2 and Figure 3.

An examination of Table 1 reveals that both parameters possess upward trends implying that the study area is warming at the rate of $0.011^{\circ} \mathrm{C}$ per annum and getting wetter by $21.26 \mathrm{~mm}$ annually. It therefore implies that both parameters possess positive trends. Similarly, all the correlation coefficients of these parameters are positive and significant at 95\% level of confidence (as in Table 2). Thus, there is no randomness in the trends of the temperature and rainfall data of Kano State. The $0.011^{\circ} \mathrm{C}$ annual rate of increase in mean annual temperatures of the study area (see Table 1 and Figure 2), could look ordinarily small. But for a typical tropical area such as Kano State, north-western Nigeria, any increase in temperature whatsoever could imply much for the other 


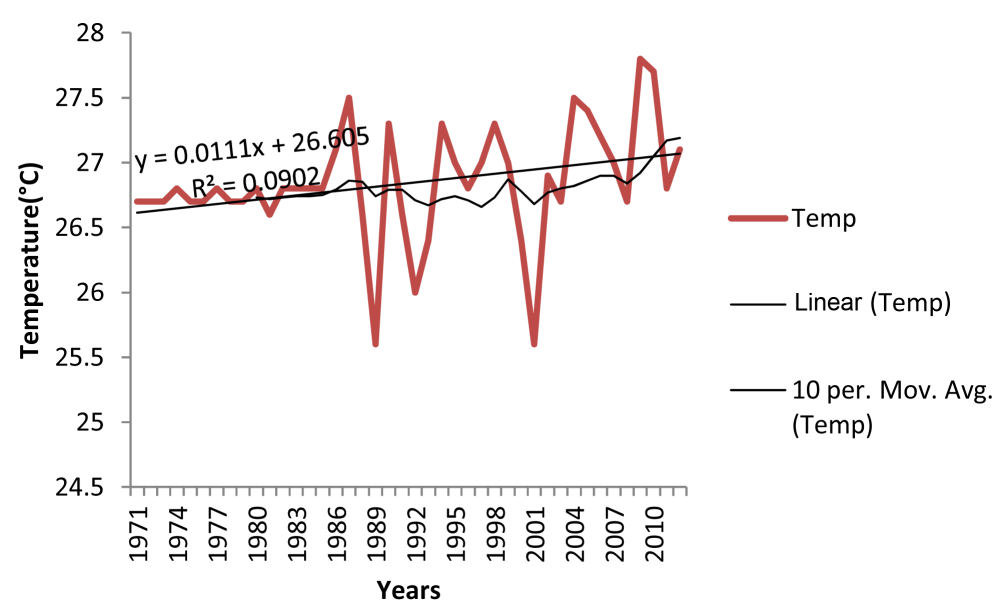

Figure 2. Trends of mean annual temperatures for Kano State.

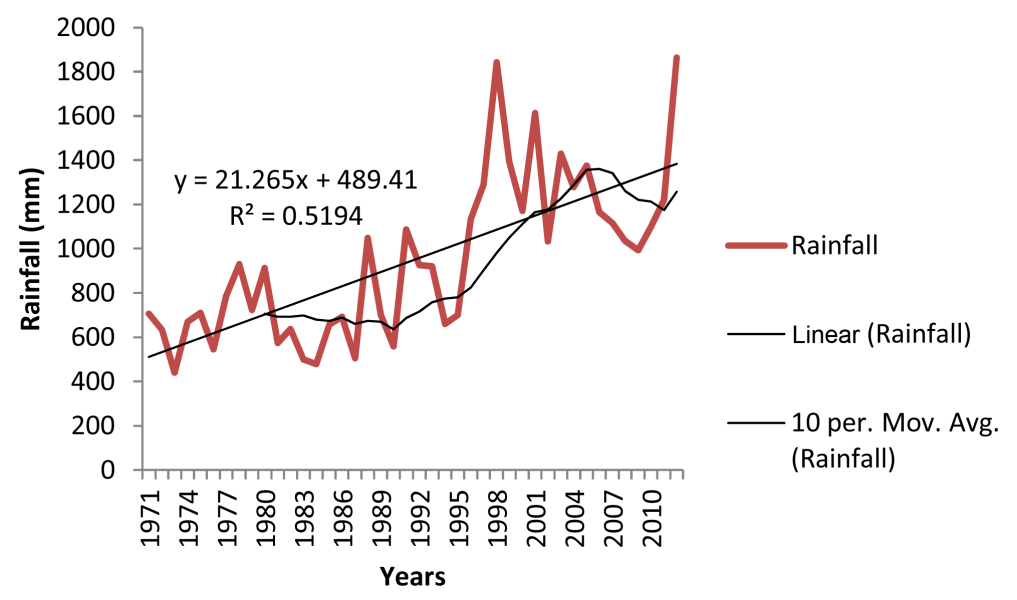

Figure 3. Trends of annual rainfall totals for Kano State.

Table 1. Prediction models for parameters used.

\begin{tabular}{cccc}
\hline $\mathbf{S} / \mathbf{N}$ & Parameter & Period & Regression line equation \\
\hline 1 & Mean annual temperatures & $1971-2013$ & $\mathrm{Y}=26.60+0.011 \mathrm{x}$ \\
2 & Annual rainfall totals & $1971-2013$ & $\mathrm{Y}=489.4+21.26 \mathrm{x}$ \\
\hline
\end{tabular}

Table 2. Correlation coefficients, coefficients of determination and significance at $95 \%$ confidence level for parameters used.

\begin{tabular}{ccccccc}
\hline S/N & Parameter & $\begin{array}{c}\text { r (correlation } \\
\text { coefficient) }\end{array}$ & $\begin{array}{c}\mathbf{r}^{2} \text { (coefficient of } \\
\text { determination) } \mathbf{( \% )}\end{array}$ & $\begin{array}{c}\text { Calculated } \\
\text { value }\end{array}$ & $\begin{array}{c}\text { Table } \\
\text { value }\end{array}$ & Result \\
\hline 1. & Mean annual temperatures & 0.3 & 9.0 & 2.02 & 1.68 & Significant \\
2. & Annual rainfall totals & 0.72 & 51.9 & 6.68 & 1.68 & Significant \\
\hline
\end{tabular}

elements of weather and climate (for example rainfall). Basically, this increase in mean annual temperatures will make the area even hotter. This would bring about increase in evapotranspiration if wet surfaces exist [20] [29].

The rate of increase in annual rainfall totals for Kano State, that is $21.26 \mathrm{~mm}$ (Table 1 and Figure 3), is way above those of other states not only in the north-western part of Nigeria but in the entire northern Nigeria which is made up of 19 states [20]. These increasing annual rainfall totals of the study area can be attributed to the increasing sizes of the dam/irrigation projects in the area (see Table 3). The two dam/irrigation projects are among the largest in Nigeria, thus making Kano State the state in Nigeria with the largest area under dam/irrigation 
Table 3. Major dam/irrigation projects in Kano State.

\begin{tabular}{cccccc}
\hline S/N & $\begin{array}{c}\text { Dam/irrigation } \\
\text { projects }\end{array}$ & $\begin{array}{c}\text { Capacity of dam } \\
\text { (million of } \mathbf{~ m}^{\mathbf{3}} \text { ) }\end{array}$ & $\begin{array}{c}\text { Expected project surface } \\
\text { area (hectares) }\end{array}$ & $\begin{array}{c}\text { Present project } \\
\text { surface area (hectares) }\end{array}$ & $\begin{array}{c}\text { Primary } \\
\text { usage }\end{array}$ \\
\hline 1 & Challawa Gorge & 930 & 25,000 & 10,117 & Water supply \\
2 & Tiga & 1874 & 25,000 & 17,800 & $\begin{array}{c}\text { Irrigation } \\
\text { and water supply }\end{array}$ \\
\hline
\end{tabular}

Modified from [30] [31].

projects that are very active. Such projects are usually a source of increasing water molecules in the earth's atmosphere wherever they exist; the reasons being that large dam/irrigation projects will cause an increase in evapotranspiration. This is in the sense that such projects increase the leaf-area as the number of plants increases, and also wet surfaces available. The tendency for condensation to take place and clouds formed, which could result in precipitation (rainfall in this case), under these circumstances is very high. These convective activities are basically temperature powered. With the warming of the study area, the increasing rainfall and its annual rate are thus not surprising. When convective activities are reduced, condensation and cloud formation are likely to be reduced too, thereby reducing the tendency for precipitation.

This increased rainfall of Kano State which is resulting from climate change through increasing temperature should be taken advantage of especially by farmers as it provides a free source of water for crop and animal production when harvested or fall over the farmlands. The rivers that recharge the dams, the dams themselves, the irrigation projects in general and groundwater are being recharged more with increasing rainfall. This further enhances agriculture directly for crop production and directly and indirectly for animal production. The animals drink from the harvested rain water, and crops produced are some sources of food or foods for the animals. Inadequate water supply is usually the bane of agriculture for an area like Kano state where rainy season is only for about 5 months. Therefore an increase in the amount of rainfall that can be harvested, stored in dams, ponds and underground is an advantage that should be seized by farmers and investors in the agricultural sector.

\section{Conclusions}

From the results and discussion, Kano State is one area that is experiencing at least one advantage of climate change by way of increasing annual rainfall totals. Though rainfall increase could mean for some areas flooding, pressure on dam walls and facilities, and so on, it is an advantage for the study area and like areas where agriculture is popular and rainfall amounts relatively small and rainy season short. Therefore, agriculture can be enhanced through this increasing rainfall. Crops that were before now not planted because of inadequate moisture can now be introduced in the area with increasing rainfall both directly and from stored ones in tanks, dams, ponds and underground. With this Kano State will maintain its pride of place as the state in Nigeria that ranks first in the production of several crops and animal products for both local and international markets.

Equally, care must be taken with this increasing annual rainfall totals to avoid it becoming a source of disaster for the area and Nigeria as a whole. This is because of the flooding that can emanate from the rainfall increase. It is therefore expedient for more dams to be built and old ones strengthened and enlarged majority by the governments of Nigeria and Kano State since such projects are capital intensive. Private-partnership participation should also be encouraged by these governments.

\section{References}

[1] Intergovernmental Panel on Climate Change (IPCC) (1996) Climate Change 1995. Cambridge University Press, New York.

[2] IPCC (2001) Climate Change 2001: The Scientific Basis. Cambridge University Press, New York.

[3] Santer, B.D., et al. (1996) A Search for Human Influences on the Rural Structure of the Atmosphere. Nature, 382, 3946. http://dx.doi.org/10.1038/382039a0

[4] Wigley, T.M.L., Smith, R.L. and Santer, B.D. (1998) Anthropogenic Influence on the Autocorrelation Structure of Hemispheric Mean Temperatures. Science, 282, 1676-1679. http://dx.doi.org/10.1126/science.282.5394.1676

[5] Crowley, T.J. (2000) Causes of Climate Changes over the Past 1000 Years. Science, 289, 270-277. http://dx.doi.org/10.1126/science.289.5477.270 
[6] Zhao, M., Pitman, A.J. and Chase, T.N. (2001) Influence of Landcover Change on the Atmospheric Circulation. Climate Dynamics, 17, 467-477. http://dx.doi.org/10.1007/PL00013740

[7] Bueh, C., Cubasch, U. and Hagemann, S. (2003) Impacts of Global Warming on Changes in the East Asian Monsoon and the Related River Discharge in Global Time-Slice Experiment. Climate Research, 24, 47-57. http://dx.doi.org/10.3354/cr024047

[8] Harvey, D.I. and Mill, T.C. (2003) Modelling Trends in Central England Temperatures. Journal of Forecasting, 22, 35-47. http://dx.doi.org/10.1002/for.857

[9] Pappas, C., Hatzianastassiou, N. and Katsoulis, B.D. (2004) Analysis of Cold Spells in the Greek Region. Climate Research, 27, 211-223. http://dx.doi.org/10.3354/cr027211

[10] Pitman, A.J. and McAvaney, B.J. (2004) Impact of Varying the Complexity of the Land Surface Energy Balance on the Sensitivity of the Australian Climate to Increasing Carbon Dioxide. Climate Research, 25, 191-203. http://dx.doi.org/10.3354/cr025191

[11] Qian, W. and Lin, X. (2004) Regional Trends in Recent Temperature Indices in China. Climate Research, 27, 119-134. http://dx.doi.org/10.3354/cr027119

[12] Alpert, P., Kaufman, Y.J., Shay-El, Y., Tanre, D., da Silva, A., Schubert, S. and Joseph, J.H. (1998) Qualification of Dust Forced Heating of the Lower Troposphere. Nature, 395, 367-370. http://dx.doi.org/10.1038/26456

[13] Miller, R.L. and Tegen, I. (1998) Climate Response to Soil Dust Aerosols. Journal of Climate, 11, 3247-3267. http://dx.doi.org/10.1175/1520-0442(1998)011<3247:CRTSDA>2.0.CO;2

[14] Dube, L.T. (2002) Climate of Southern Africa. The South African Geographical Journal, 84, 125-138. http://dx.doi.org/10.1080/03736245.2002.9713763

[15] Obioha, E.E. (2005) Climate Change, Population Drift and Violent Conflict over Land Resources in North Eastern Nigeria. Proceedings of the International Workshop on Human Security and Climate Change, Asker, Oslo, 21-23 June 2005.

[16] Ekanem, E.M. and Nwagbara, M.O. (2010) Climate Change, Desertification and Dust Generation in Nigeria: A Review. Journal of Environmental Systems, 32, 5-15. http://dx.doi.org/10.2190/ES.32.1.b

[17] Ayres R.U. and Walter, J. (1991) The Greenhouse Effect: Damages Costs and Abatement. Environmental and Resources Economics, 1, 237-270. http://dx.doi.org/10.1007/BF00367920

[18] Anonymous (2005) Preparing for a Warmer World. Spore, No. 117, 1-2.

[19] Meyer, W.B. (1996) Human Impact on Earth. Cambridge University Press, New York.

[20] Nwagbara, M.O. (2008) Landcover Change in Relation to Climate Change in Northern Nigeria Using GIS Techniques. Ph.D. Dissertation, Abia State University, Uturu.

[21] Abaje, I.B., Ndabula, C. and Garba, A.H. (2014) Is the Changing Rainfall Patterns of Kano State and Its Adverse Impacts an Indication of Climate Change? European Scientific Journal, 10, 192-206.

[22] Nabegu, A.B. (2014) Analysis of Vulnerability to Food Disaster in Kano State, Nigeria. Greener Journal of Physical Sciences, 4, 22-29.

[23] Oyewole, S.O. and Ojeleye, O.A. (2015) Factors Influencing the Use of Improved Farm Practices among Small-Scale Farmers in Kano State of Nigeria. Net Journal of Agricultural Science, 3, 1-4.

[24] Olofin, E.A. (2008) The Physical Setting. In: Olofin, E.A., Nabegu, A.B. and Dambazau, A.M., Eds., Wudil within Kano Region: A Geographical Synthesis, Adamu Joji Publishers, Kano City, 5-34.

[25] National Population Commission (2007) 2006 Population Census of Nigeria. NPC, Abuja.

[26] Hammond, R. and McCullagh, P. (1978) Quantitative Techniques in Geography: An Introduction. John Wiley, London.

[27] Owen, F. and Jones, R. (1994) Statistics. 4th Edition, Longman, London.

[28] Anyadike, R.N.C. (2009) Statistical Methods for the Social and Environmental Sciences. Spectrum Books, Ibadan.

[29] Chima, G.N., Nwagbara, M.O. and Ijioma, M.A. (2009) Rainfall Response to Dam/Irrigation Projects in Northern Nigeria. Global Journal of Social Science, 8, 41-50. http://dx.doi.org/10.4314/gjss.v8i1.48877

[30] Ita, E.O., Sado, E.K., Balogun, J.K., Pandogari, A. and Ibitoye, B. (1985) A Preliminary Checklist of Inland Water Bodies in Nigeria with Special Reference to Lakes and Reservoirs. Kainji Lake Research Institute, Kainji.

[31] Enplan Group (2004) Review of the Public Sector Irrigation in Nigeria. Federal Ministry of Water Resources/UN Food and Agricultural Organization, Abuja. 